\title{
Assessment of coagulation and fibrinolytic factors among patients with type 2 diabetes mellitus in University of llorin Teaching Hospital, llorin, Nigeria
}

\author{
Abolarin Ademola Toyosi, ${ }^{1}$ Olawumi Hannah Oluwayemisi, ${ }^{2}$ Durotoye Idayat Adenike, ${ }^{2}$ \\ Olarinoye John Kola, ${ }^{3}$ Olufemi-Aworinde Kehinde Joyce ${ }^{1}$ \\ ${ }^{1}$ Department of Haematology and Blood Transfusion, Bowen University Teaching Hospital, Ogbomosho, Oyo \\ State; ${ }^{2}$ Department of Haematology and Blood Transfusion, University of Ilorin Teaching Hospital, Kwara State; \\ ${ }^{3}$ Department of Internal Medicine, University of Ilorin Teaching Hospital, Kwara State, Nigeria
}

\begin{abstract}
Diabetes mellitus is characterized by major changes in the coagulation and fibrinolytic system. The study was aimed at
\end{abstract}

\author{
Correspondence: Abolarin Ademola Toyosi, Department of \\ Haematology and Blood Transfusion, Bowen University Teaching \\ Hospital, Ogbomoso, Oyo State, Nigeria. \\ Tel.: +234.7032691801. \\ E-mail: demola.abolarin@gmail.com
}

Key words: Type 2 diabetes; hypercoagulable state; North-central Nigeria.

Acknowledgements: This study was conducted at the department of Haematology, University of Ilorin teaching Hospital, Ilorin, Kwara State, Nigeria. The authors would like to thank all the study participants for their time and effort in completing this study and the management of the University of Ilorin teaching hospital for the logistic support during this study.

Contributions: AAT: concept, design, writing, analysis, literature search, critical review. DIA: design, writing, literature search, critical review, supervision. O-AKJ: supervision, critical review. OHO: supervision, analysis, critical review, design. OJK: literature search, critical review, supervision.

Conflicts of interest: The authors declare no conflict of interest.

Ethics approval and consent to participate: Approval for this study was sought and obtained from the Hospital Ethics and Research Committee. Ethics Committee number: ERC PAN/2016/05/1539. Written and informed consent was obtained from the patients after thorough explanation of the aim of the study and the procedure involved in a language best understood by them.

Availability of data and materials: The data used to support the findings of this study are available from the corresponding author upon request.

Received for publication: 24 November 2020.

Revision received: 5 February 2021.

Accepted for publication: 22 February 2021.

This work is licensed under a Creative Commons Attribution NonCommercial 4.0 License (CC BY-NC 4.0).

${ }^{\circledR}$ Copyright: the Author(s), 2021

Licensee PAGEPress, Italy

Annals of Clinical and Biomedical Research 2021;2:121

doi:10.4081/acbr.2021.121 assessing the degree of changes in the coagulation and fibrinolytic system in patients with type 2 diabetes mellitus in North-central Nigeria. This was a hospital based comparative Cross-sectional study involving 78 type 2 diabetics and 78 healthy controls. Full blood count was performed using Sysmex XP 300 according to manufacturer's instructions. Prothrombin time was determined using one stage test of Owren. Activated partial thromboplastin time was determined by method of Proctor and Rapaport. Fibrinogen assay was determined using AssayMax Human Fibrinogen ELISA. Plasminogen Activator Inhibitor type-1 was determined using the AssayMax Human PAI-1 ELISA kit. The mean age of the subjects and controls were $60.73 \pm 10.8$ and 59.65 \pm 12.7 years respectively. The mean diastolic blood pressure of subjects with Diabetes was significantly higher than that of the controls $(91.84 \pm 11.02$ vs $87.58 \pm 11.3:$ p-value $=0.002)$. The mean Prothrombin time, Fibrinogen concentration and PAI- 1 level were significantly higher in the subjects than the controls $(p=$ $0.047,0.031 \& 0.020)$. No significant differences were observed in Platelet count, APTT and INR $(\mathrm{P}=0.938,0.664 \& 0.059$ respectively). This study confirms that diabetes mellitus is a cause of hypercoagulable state as evidenced by the significant alteration in the coagulation and fibrinolytic system. There is need for proper glycaemic control in patients with diabetes.

\section{Introduction}

Diabetes Mellitus (DM) is a metabolic and complex endocrine disease. The prevalence is rapidly rising all over the globe and has thus been described as epidemic of the twenty-first century. ${ }^{1}$ Factors contributing to this rising trend include urbanization and lifestyle changes, including increasingly sedentary lifestyles, less physical demanding work and global nutrition, marked by increased intake of foods that are high in energy but nutrientpoor. ${ }^{1,2}$ Diabetes used to be a disease of middle age and elderly but with epidemiologic transition it is being seen more among young adults. ${ }^{3}$ It is an important public health problem, one of the four priority non-communicable diseases targeted for action by world leaders. ${ }^{4}$ About $85-90 \%$ of all cases are type 2 diabetes, however the two conditions can overlap. ${ }^{5,6}$ In 2016, WHO estimated that about 422 million adults were living with diabetes mellitus while the prevalence of diabetes for all age groups rose from $2.8 \%$ in the year 2000 to $8.5 \%$ in $2014.1,2,7$ The prevalence of diabetes varies from $1-7 \%$ in Nigeria. Type 2 Diabetes accounts for $13.4 \%$ of medical admissions in Enugu, $14.6 \%$ in Abia and 5.1\% in Ilorin. ${ }^{8-10}$ Furthermore, a study done by Edem et al. put the incidence at $4 \%$ in Calabar, South-South Geopolitical region. ${ }^{11}$

Diabetes and cardiovascular disease are not of mandatory notification and are currently the greatest public health problem responsible for the increased morbidity and mortality seen in the 
21 st century. ${ }^{12}$ The WHO estimates that diabetes accounted for 1.5 million deaths worldwide in 2012 making it the $8^{\text {th }}$ leading cause of death. ${ }^{1}$ Microvascular and macrovascular abnormalities are the major complications of diabetes mellitus. ${ }^{13,14}$ The most common microvascular complications are nephropathy, retinopathy and neuropathy and the most important macrovascular complications include coronary artery disease, strokes and peripheral arterial disease. ${ }^{15-17}$

Diabetes mellitus is accompanied by major changes in all aspect of haemostasis. Vascular endothelium, platelet, coagulation factors and co-factors, the natural anticoagulant as well as fibrinolytic pathway are adversely affected in this disease. The levels of coagulation factors are all increased in diabetes. Factor VII, VIII, vWF and fibrinogen levels are significantly enhanced whereas levels of naturally occurring anticoagulants such as antithrombin, protein $\mathrm{C}$ and $\mathrm{S}$ are reduced and increase level of plasminogen activator inhibitor type-1 which decreases fibrinolysis thus supporting diabetes as a cause of hypercoagulable state. ${ }^{18}$ About $80 \%$ of diabetics die from thrombotic events with $75 \%$ to $80 \%$ of these deaths resulting from cardiovascular events and the risk of which doubled in diabetes resulting in significant reduction in life expectancy. ${ }^{18,19}$ An increase in FVIII and fibrinogen plasma levels are considered an independent risk factor for thrombo-embolism. Hypofibrinolysis is a key abnormality in individual with diabetes. Plasminogen activator inhibitor type 1 (PAI-1) is an important inhibitor of the fibrinolytic pathway. Its level is significantly elevated in patient with type 2 diabetes mellitus and it's an independent risk factor for cardiovascular disease. Plasminogen activator inhibitor (PAI-1) inhibits plasmin, t-PA and u-PA, thus favoring permanence of fibrin clot. $^{20}$

The costs involved in treating diabetes and its associated complications are high and most of these are borne by the affected individual as the level of health insurance coverage is still low in Nigeria, thus impacting harshly on the finances of individuals, their families as well as on the economy of the nation. It is therefore important for the government to invest heavily in primary prevention (to reduce the incidence of DM) and secondary prevention (to reduce the immediate and long-term complications of diabetic patients).

There is paucity of data on coagulation system in diabetic patients in Nigeria and especially in University of Ilorin Teaching Hospital that serves as a referral centre for other neighboring states. The aim of this study therefore was to assess the degree of impairment of coagulation and fibrinolytic factors among type 2 diabetes mellitus patients in Ilorin, Nigeria.

\section{Materials and Methods}

\section{Study design}

This was a hospital based comparative case-control study. Approval for this study was sought and obtained from the Hospital Ethics and Research Committee (Ethics Committee number: ERC PAN/2016/05/1539).

Written and informed consent was obtained from the patients after thorough explanation of the aim of the study and the procedure involved in a language best understood by them.

Fishers formula ${ }^{21}$ was used in calculating the sample size and 70 was the minimum sample size calculated and $10 \%$ attrition rate was also factored in arriving at the sample size of 78 for this study.

A total of 78 type 2 diabetic patients (both new and follow up cases) diagnosed based on WHO criteria for diagnosis of diabetes, who met the inclusion criteria for this study were recruited using convenience sampling method. Patients with impaired hepatic synthetic function, varicose veins, previous history of heart disease, history of bleeding disorders, use of antiplatelet or anticoagulant medications, as well as those who refused to give consent, were excluded from the study. Seventy-eight age and sex matched staff of the hospital and voluntary blood donors who consented to participate in this study and met the inclusion criteria as the subject were selected using simple random sampling, and used as controls.

Structured interviewer administered questionnaires were used to obtain relevant data and history from each participant. Each subject was examined following this sequence: general physical examination, abdominal and cardiac examination. Blood pressure was measured with a mercury sphygmomanometer (Accosson England) with a standard cuff $(25 \mathrm{~cm}=12 \mathrm{~cm})$ in sitting position on the right arm after at least 30 minutes rest. The weight and height were determined using standard weighing scale and stadiometer. Body Mass Index (BMI) was calculated using WHO reference method and documented; $7.5 \mathrm{~mL}$ of venous blood collected was immediately separated into two: $4.5 \mathrm{~mL}$ into plastic tube containing $0.5 \mathrm{~mL}$ trisodium citrate and $3.0 \mathrm{~mL}$ into EDTA bottle. Appropriate referral was made to managing consultants for the diabetic subject with complications. $4.5 \mathrm{~mL}$ of sample taken was dispensed into plastic tube containing $0.5 \mathrm{~mL}$ trisodium citrate (3.8\%) tightly capped and mixed gently. The sample was centrifuged at $2000 \mathrm{~g}$ for 15 minutes, there after the plasma was transferred into a plastic centrifuge tube without disturbing the buffy coat and cell layers. The plasma in the centrifuge tube was spun again at $2000 \mathrm{~g}$ for another 15 minutes to obtain platelet poor plasma. The platelet poor plasma was separated using a plastic transfer pipette and placed in plastic aliquot tubes and then tightly capped. The sample was stored at $-80^{\circ} \mathrm{C}$ until assayed for the coagulation tests; PT, APTT, Fibrinogen and Plasminogen activator inhibitor type 1 (PAI-1). The sample in the Ethyelene Diamine Tetra acetic Acid (EDTA) bottle was used for analysis of full blood count, which was performed using Sysmex XP 300, automated cell counter with strict adherence to manufacturer's instructions within two hours of sample collection.

Prothrombin time was determined using commercially prepared reagents based on the one stage test of Owren. ${ }^{22}$ Activated partial thromboplastin time was determined using commercially prepared reagents based on method of Proctor and Rapaport. ${ }^{23}$ Fibrinogen assay was determined using AssayMax Human Fibrinogen ELISA (commercially prepared and obtained from Assaypro LLC, 3400 Harry S Truman Blvd,St Charles, MO 63301). Plasminogen Activator Inhibitor type -1wasdetermined using the AssayMax Human PAI-1 ELISA kit (Product of Saint Charles, Missouri, USA).

Data entry and analysis were done with a micro-computer using Statistical Package for the Social Sciences (SPSS) version 20.0 computer software packages. Data collected from the study proforma were entered using numeric codes. All subjects were grouped. Results were presented in tabular forms or figures as found applicable. Categorical data were compared by chi square and statistical significance were tested at predetermined $P$ value of $<0.05$ while Mann- Whitney U tests were used to determine significant differences between skewed data. 
Table 1. Socio-demographic characteristics of respondents.

\section{Results}

A total of 156 participants, including 78(100.0\%) type 2 diabetic subjects and 78(100.0\%) age and sex matched non- diabetic healthy controls, were recruited for this study. The mean age of the subjects and controls were $60.7 \pm 10.8$ and $59.7 \pm 12.7$ years respectively. Majority of the subjects $(66.7 \%)$ were within the ages of 50 - 65 years. There were more female participants than males (65.4\% compared $34.6 \%$, Table 1$)$.

About $30 \%$ of the subjects and controls were obese. More patients with type 2 diabetes $(10.3 \%)$ took alcohol as compared to the controls (3.8\%). The mean diastolic blood pressure of subjects with DM was significantly higher than that of the controls $(91.8 \pm$ 11.0 versus $87.6 \pm 11.3$ : $\mathrm{p}$-value $=0.002)$, There were however no statistically significant differences in the BMI and Systolic blood pressures between both groups (Table 2).

The mean Prothrombin time, Fibrinogen concentration and PAI-1 level was significantly higher in the subjects than in the controls $(\mathrm{p}=0.047,0.031 \& 0.020)$. No significant differences were observed in Platelet count, APTT and INR between subjects and controls $(\mathrm{P}=0.938,0.664 \& 0.059$ respectively, Table 3$)$.

There were no significant correlations between Fibrinogen level with BMI, Diastolic blood pressure and systolic blood pressure among the subjects and control $(\mathrm{p}=0.975,0.675 \& 0.545)$. There was also no significant correlation between PAI-1 with BMI, Diastolic blood pressure and systolic blood pressure among the subjects and control ( $\mathrm{p}=0.637,0.563 \& 0.524$, Table 4$)$.

\section{Discussion}

The mean age of respondents with Type 2 diabetes in this study

\begin{tabular}{|c|c|c|}
\hline Variable & Subjects (\%) & Controls (\%) \\
\hline $\begin{array}{l}\text { Age group (years) } \\
\quad \leq 50 \\
\quad 50-65 \\
\quad>65\end{array}$ & $\begin{array}{l}12(15.4) \\
52(66.7) \\
14(17.9)\end{array}$ & $\begin{array}{l}11(14.1) \\
54(69.2) \\
13(16.7)\end{array}$ \\
\hline $\begin{array}{l}\text { Sex } \\
\quad \text { Male } \\
\text { Female }\end{array}$ & $\begin{array}{l}20(25.6) \\
58(74.4)\end{array}$ & $\begin{array}{l}34(43.6) \\
44(56.4)\end{array}$ \\
\hline $\begin{array}{l}\text { Marital status } \\
\text { Single } \\
\text { Married } \\
\text { Separated } \\
\text { Widow/widower }\end{array}$ & $\begin{array}{c}1(1.3) \\
63(80.8) \\
- \\
14(17.9)\end{array}$ & $\begin{array}{c}5(6.4) \\
69(88.5) \\
1(1.3) \\
3(3.8)\end{array}$ \\
\hline $\begin{array}{l}\text { Level of Education } \\
\text { No formal education } \\
\text { Primary } \\
\text { Secondary } \\
\text { Tertiary } \\
\text { Arabic }\end{array}$ & $\begin{array}{c}29(37.2) \\
10(12.8) \\
8(10.3) \\
31(39.7) \\
-\end{array}$ & $\begin{array}{c}18(23.1) \\
8(10.3) \\
8(10.3) \\
43(55.1) \\
1(1.3)\end{array}$ \\
\hline $\begin{array}{l}\text { Religion } \\
\text { Islam } \\
\text { Christianity }\end{array}$ & $\begin{array}{l}43(55.1) \\
35(44.9)\end{array}$ & $\begin{array}{l}22(28.2) \\
56(71.8)\end{array}$ \\
\hline $\begin{array}{l}\text { Occupation } \\
\text { Unemployed } \\
\text { Unskilled Labor } \\
\text { Skilled Labor } \\
\text { Professional } \\
\end{array}$ & $\begin{array}{l}12(15.4) \\
34(43.6) \\
4(5.1) \\
28(35.9)\end{array}$ & $\begin{array}{c}7(9.0) \\
28(35.9) \\
11(14.1) \\
32(41.0)\end{array}$ \\
\hline $\begin{array}{l}\text { Ethnicity } \\
\text { Yoruba } \\
\text { Igbo } \\
\text { Hausa } \\
\text { Nupe } \\
\text { Baruten } \\
\end{array}$ & $\begin{array}{c}74(94.9) \\
3(3.8) \\
- \\
1(1.3) \\
- \\
\end{array}$ & $\begin{array}{c}73(93.6) \\
2(2.6) \\
1(1.3) \\
1(1.3) \\
1(1.3)\end{array}$ \\
\hline
\end{tabular}

Table 2. Comparison of clinical parameters between type 2 diabetics and controls.

\begin{tabular}{|c|c|c|c|c|}
\hline Variables & $\begin{array}{c}\text { Diabetic } \\
\mathrm{n}=78\end{array}$ & $\begin{array}{c}\text { Control } \\
n=78\end{array}$ & $\begin{array}{l}\text { Mann Whitney } \\
\text { U test }\end{array}$ & p -value \\
\hline $\begin{array}{l}\text { BMI }\left(\mathrm{kg} / \mathrm{m}^{2}\right) \\
\text { Range Mean } \pm(\mathrm{SD})\end{array}$ & $\begin{array}{c}21.3 \\
28.72 \pm 5.97\end{array}$ & $\begin{array}{c}31.51 \\
27.83 \pm 6.04\end{array}$ & 22.50 & 0.065 \\
\hline $\begin{array}{l}\text { Systolic Blood } \\
\text { Pressure }(\mathrm{mmHg}) \\
\text { Range Mean } \pm(\text { SD) }\end{array}$ & $\begin{array}{c}100.0 \\
142.5 \pm 21.33\end{array}$ & $\begin{array}{c}90.00 \\
134.7 \pm 17.7\end{array}$ & 10.50 & 0.815 \\
\hline $\begin{array}{l}\text { Diastolic Blood } \\
\text { Pressure (mmHg) } \\
\text { Range Mean } \pm \text { (SD) }\end{array}$ & $\begin{array}{c}50.00 \\
91.84 \pm 11.02\end{array}$ & $\begin{array}{c}50.00 \\
87.58 \pm 11.3 \\
\end{array}$ & 25.50 & 0.002 \\
\hline
\end{tabular}

Table 3. Comparison of haematological and haemostatic parameters between Type 2 Diabetics and controls.

\begin{tabular}{|c|c|c|c|c|}
\hline Variables & $\begin{array}{c}\text { Diabetic } \\
\mathbf{n}=78\end{array}$ & $\begin{array}{c}\text { Control } \\
n=78\end{array}$ & $\begin{array}{c}\text { Mann Whitney } \\
\text { U test }\end{array}$ & p \\
\hline $\begin{array}{l}\text { Platelet Count }\left(\times 10^{9}\right) \\
\text { Mean (SD) Median }\end{array}$ & $\begin{array}{l}259.1(129.4) \\
220.0\end{array}$ & $\begin{array}{l}267.8(163.1) \\
245.0\end{array}$ & 29.00 & 0.938 \\
\hline $\begin{array}{l}\text { PT (secs) } \\
\text { Mean (SD) Median }\end{array}$ & $\begin{array}{c}12.80(1.90) \\
12.00\end{array}$ & $\begin{array}{c}12.69(1.99) \\
12.00\end{array}$ & 50.25 & 0.047 \\
\hline $\begin{array}{l}\text { INR } \\
\text { Mean (SD) Median }\end{array}$ & $\begin{array}{c}1.07(0.165) \\
1.00\end{array}$ & $\begin{array}{c}1.06(0.172) \\
1.00\end{array}$ & 75.23 & 0.059 \\
\hline $\begin{array}{l}\text { APTT (secs) } \\
\text { Mean (SD) Median }\end{array}$ & $\begin{array}{l}31.52(5.47) \\
30.00\end{array}$ & $\begin{array}{c}33.10(6.99) \\
32.00\end{array}$ & 13.000 & 0.6640 \\
\hline $\begin{array}{l}\text { PAI } 1 \text { (ng/mL) } \\
\text { Mean (SD) Median }\end{array}$ & $\begin{array}{c}2.94(2.54) \\
2.08 \\
\end{array}$ & $\begin{array}{c}1.68(3.47) \\
1.60 \\
\end{array}$ & 13.000 & 0.020 \\
\hline
\end{tabular}


was $60.73 \pm 10.8$, a finding similar to an earlier study by Adediran et al who reported a mean age of $56.7 \pm 12$ and $55.7 \pm 8.5$ years among female and male subjects respectively. ${ }^{24}$ It is however much higher than $51.8 \pm 10.2$ years reported by Alao et al. in the Northern part of Nigeria. ${ }^{25}$ This could be attributed to the lower sample population in the Alao study, and also to the fact that the study was carried out in northern Nigeria, where cultural beliefs, poverty, and illiteracy may contribute to a poor health seeking attitude among the elderly.

The majority of the respondents in this study were between 46-65 years of age. This is similar to an earlier study report by Iloh et al., who found that type 2 diabetes was commonest in patients between $40-60$ years. ${ }^{26}$ The International Diabetes Federation states that $80 \%$ of people living with type 2 diabetes are middle aged, and live in low and medium income countries such as Nigeria, thus corroborating the findings of this current study. ${ }^{27}$

There was also a higher number of female respondents compared to males in this study, and the percentage of females with type 2 diabetes was $74.4 \%$. This finding was similar to what was reported by Alao et al. and Iloh et al. ${ }^{25,26}$ study done in Turkey revealed a similar finding of more women with Type 2 Diabetes, and reported prevalence of $53.2 \%$ and $46.8 \%$ among women and men respectively. ${ }^{28}$ More studies in the developed countries, however show an increase in the prevalence of men with Type 2 Diabetes in contrast to the findings of this study. Nordstrom et al. in Sweden reported $14.6 \%$ of men and $9.6 \%$ of women having type 2 diabetes, while Lipscombe and Hux in Canada reported a prevalence of $19.1 \%$ to $15.4 \%$ between middle aged men and women. ${ }^{29,30}$ The observed increase in prevalence of men with Type 2 Diabetes mellitus as compared to the index study can be attributed to the better health seeking attitudes and reduced influence of negative cultural beliefs among men in developed countries, compared to Nigerian men.

The current study reports that $60.8 \%$ of type 2 diabetic subjects were either obese or overweight with an equal distribution among the two groups. This constituted the majority of patients. Fadupin et al. also reported a similar finding among type 2 diabetics in Ibadan. ${ }^{31}$ This is also similar to studies carried out by Mugharbel et al. in India. ${ }^{32}$ The mean BMI in the index study was also higher in subjects when compared to controls $(28.72 \pm 5.97$ vs $27.83 \pm$ $6.04)$ and is similar to several earlier reports..$^{25,26}$ Obesity has been shown to have a significant positive association with suboptimal glycemic control and insulin resistance, while it is negatively associated with insulin sensitivity. ${ }^{31,32}$ The findings in the index study are thus unsurprising, and suggest a closer relationship between

Table 4. Correlation between PAI 1 (ng/mL) and Fibrinogen levels $(\mathrm{mg} / \mathrm{dL})$ with clinical parameters among Diabetics and Controls.

\begin{tabular}{|c|c|c|}
\hline Variable & $\begin{array}{c}\text { Diabetics } \\
\left.\text { ( } \mathrm{r}^{*}, \mathrm{p} \text {-value }\right)\end{array}$ & $\begin{array}{c}\text { Controls } \\
\left.\text { ( } \mathrm{r}^{*}, \mathrm{p} \text {-value }\right)\end{array}$ \\
\hline \multicolumn{3}{|l|}{ PAI-1 } \\
\hline Systolic Pressure & $0.153,0.381$ & $0.047,0.637$ \\
\hline Diastolic Pressure & $0.217,0.217$ & $0.058,0.563$ \\
\hline BMI & $0.069,0.686$ & $-0.108,0.524$ \\
\hline Duration of treatment & $-0.130,0.447$ & - \\
\hline \multicolumn{3}{|l|}{ Fibrinogen } \\
\hline Systolic Pressure & $0.127,0.468$ & $0.043,0.975$ \\
\hline Diastolic Pressure & $0.197,0.258$ & $-0.047,0.675$ \\
\hline BMI & $-0.108,0.524$ & $-0.067,0.545$ \\
\hline Duration of treatment & $-0.049,0.774$ & - - \\
\hline
\end{tabular}

*= Pearson's correlation coefficient; PAI-1: Plasminogen activator Inhibitor Type 1.
BMI and onset of type 2 diabetes. ${ }^{27}$ In this study, it was observed that while more of the control participants had normal BMI, an equal number of them were obese when compared with type 2 diabetic subjects. This finding is disturbing considering the numerous risk factors associated with obesity. It can also be attributed to the ongoing westernization and an increase in sedentary lifestyle in the population among third world countries. ${ }^{2}$

Type $2 \mathrm{DM}$ has been described as a hypercoagulable state. ${ }^{13,14}$ This results in a tendency to shift the thrombo-haemorheologic balance in favour of thrombosis with a consequent shortening of the Prothrombin time and APTT. ${ }^{25}$ In this study, the mean values for the PT and APTT were in the normal range, as were INR values in subjects and controls. However, while the mean APTT was shorter in type 2 diabetic subjects than controls, the mean prothrombin time was found to be longer in diabetics. These results are similar to those of Erem et al., who found a slightly higher APTT among controls, but a higher Prothrombin level among Diabetics, though all values were in the normal range. ${ }^{28}$ Karim et al. and Zhao et al. reported significantly shorter PT and APTT values among Diabetics when compared to controls. ${ }^{33,34}$ The index study population comprised of both hypertensive and non-hypertensive Type 2 Diabetics. Adonu et al. found significantly shortened APTT values among hypertensive diabetics in Eastern Nigeria. ${ }^{35}$ However, there have been contrasting views as several other studies found no significant difference between the two groups. ${ }^{36,37}$ Also, Alao et al. reported prolonged PT and APTT values among type 2 diabetics. $^{25}$ These findings emphasize the fact that a lot of details surrounding coagulation in diabetes are still unknown. The hypercoagulable state is reportedly due to an increase in factor VIII concentrations and increased factor VIII binding to vWF among Type 2 Diabetics. ${ }^{20}$ Hypercoagulability markers, such as prothrombin fragment $1+2(\mathrm{~F} 1+2)$, ThrombinAntithrombin Complex (TAT) and fibrinopeptide A (FPA) are also elevated in diabetic patients. ${ }^{37}$ It is known that the increase in coagulation factors are related to the dyslipidemic conditions associated with Type 2 Diabetes.

This present study found that fibrinogen levels were significantly higher in the diabetic respondents than in controls. This is unsurprising considering the fact that fibrinogen is an acute phase protein, and the interplay between hyperglycemia and the endothelium consequently leads to inflammation-induced increases in fibrinogen levels. Several other studies also reported similar findings. ${ }^{24,28,38}$ These results are further buttressed by Kannel et al., who found a significant positive correlation between plasma glucose and fibrinogen levels, while Festa has suggested that raised fibrinogen levels are predictive of development of Type 2 diabetes in healthy individuals. ${ }^{39,40}$

Plasminogen Activator Inhibitor type 1 is a primary regulator of fibrinolysis and its actions on Tissue plasminogen activator make it central in the fibrinolytic pathway. It is expected that, given the hypofibrinolytic and hypercoagulable state in Type 2 Diabetes, PAI-1 levels among Diabetics will be elevated when compared to healthy controls. This study found higher mean PAI1 values among the Diabetic subjects. This is similar to the findings reported by several earlier studies. ${ }^{28,41-43}$ There is a paucity of published reports regarding PAI-1 levels among Nigerians with type 2 Diabetes. However, Adediran et al. reported a significant decrease in fibrinolysis by comparing Euglobin clot lysis times among Diabetics and controls. ${ }^{24}$

These observed differences are thus not surprising, and can be attributed to PAI-1 synthesis by adipocytes, with visceral fat secreting more PAI - 1 than subcutaneous fat in the obese phenotype. ${ }^{43}$ In this study, $68 \%$ of Diabetic respondents were either over- 
weight, obese or morbidly obese. Experimental studies also show that glucose up-regulates PAI-1 gene expression in vascular smooth muscle cells, endothelial cells, and adipose tissue. ${ }^{39}$ Thus, it could be expected that as glucose levels rise, enhanced PAI-1 gene expression would result in elevated circulating PAI-1 concentrations in diabetes and thus corroborating diabetes as a hypercoagulable state.

\section{Conclusions}

The mean Prothrombin time, Fibrinogen concentration and PAI- 1 level were significantly higher in the type 2 diabetics than controls subjects and thus these findings confirms that diabetes mellitus is a cause of hypercoagulable state as evidenced by the significant alteration in the coagulation and fibrinolytic system in this disease. This further buttresses the need for proper glycaemic control in order to avert the risk of cardiovascular event in affected patient.

\section{References}

1. Roglic G, Varghese C, Riley L, et al. Global Report on Diabetes. Geneva. World Health Organization, 2016. Report No: ISBN 9789241565257 (NLM classification: WK 810).

2. Wild S, Roglic G, Green A, et al. Global Prevalence of diabetes: Estimates for the year 2000 and Projections for 2030. Diabetes care 2004:27:1047-53.

3. International Diabetes Federation. IDF Diabetes Atlas 9th ed. Brussels, Belgium. 2019. Available from: http://www.idf.org/diabetesatlas

4. World Health Organization. Global Action Plan for the Prevention and Control of Non-Communicable Diseases 20132020. Geneva. World Health Organization, 2013. Report No: ISBN 9789241506236 (NLM classification: WT 500).

5. Type 2 Diabetes Mellitus. In: Kroneberg H, Melmed S, Polonsky K, Reed Larsen P, Editors: Williams Textbook of Endocrinology (12th Ed) Philadelphia, Elsevier/Saunders. PP 1371-1435. ISBN 978-1-4377-0324-5.

6. Australian Indigenous HealthInfoNet. 2020. Diabetes - Health Topics - Australian Indigenous Healthinfonet. Accessed 28 June 2020. Available from: https://healthinfonet.ecu. edu.au/learn/health-topics/diabetes/

7. Ogbera AO, Ekpebegh C. Diabetes mellitus in Nigeria: The past, present and future. World J Diabetes 2014;5:905-11.

8. Okafor CI, Ofoegbu EN. Indications and Outcome of Admission of Diabetic Patients into the medical wards in a Nigerian Tertiary Hospital. Niger Med J 2011;52:86-9.

9. Ngwogu KO, Mba IEK, Ngwogu AC. Morbidity patterns of community research at the Abia state university teaching hospital, Aba, Nigeria. IJCR 2001;1:49-53.

10. Chijioke A, Adamu A, Makusidi A. Mortality patterns among type 2 diabetes mellitus patients in Ilorin, Nigeria. JEMDSA 2010;15:79-82.

11. Edem M, Emeribe A, Akpotuzor J. Haemorrheologic and fibrinolytic activities in diabetics resident in Calabar, Cross-River State, Nigeria. Afr J Biotechnol 2008;7:1400-3.

12. Zimmet P, Alberti KG, Shaw J. Global and societal implications of the diabetes epidemic. Nature 2001;414:782-7.

13. Yamada T, Sato A, Nishimori T, Mitsuhashi T, Terao A, Sagai $\mathrm{H}$ et al. Importance of hypercoagulability over hyperglycemia for vascular complication in type 2 diabetes. Diabetes Res Clin
Pract 2000;49:23-31.

14. Nazimek-Siewniak B, Moczulski D, Grzeszczak W. Risk of macrovascular and microvascular complications in Type 2 diabetes: results of longitudinal study design. J Diabetes Complications 2002;16:271-6.

15. Brownlee M. Biochemistry and molecular cell biology of diabetic complications. Nature 2001;414:813-20.

16. Fuller JH, Stevens LK, Wang SL. Risk factors for cardiovascular mortality and morbidity: the WHO Mutinational Study of Vascular Disease in Diabetes. Diabetologia 2001;44:S54-64.

17. Bennett PH, Lee ET, Lu M, et al. Increased urinary albumin excretion and its associations in the WHO Multinational Study of Vascular Disease in Diabetes. Diabetologia 2001;44:S37-45.

18. Carr ME. Diabetes melito: a hypercoagulable state. J Diabetes Complications 2001;15:44-54.

19. Sowers JR, Epstein M, Frohlich ED. Diabetes, hypertension, and cardiovascular disease: an update. Hypertension. 2001;37:1053-9. Erratum in: Hypertension 2001;37:1350. Comment in: Hypertension 2001;38:E11.

20. Soares A, Sousa M, Fernandes A, Carvalho M. Hemostatic changes in patients with type 2 diabetes mellitus. Rev Bras Hematol Hemoter 2010;32:482-8.

21. Subject selection. In: Araoye MO, (ed.) Research Methodology With Statistics For Health and Social Sciences. Ilorin Nathadex 2003:118-9.

22. Owren PA, Aas K. The control of dicumarol therapy and the quantitative determination of prothrombin and proconvertin. Scand J Clin Lab Invest 1951:3:201-8.

23. Proctor RR, Rappaport SI. The partial thromboplastin time with kaolin. A simple screening test for first stage plasma clotting factor deficiencies. Am J Clin Pathol

1961;36:212-9.

24. Adediran I. Fibrinolytic activity in Nigerian diabetics. Postgrad Med J 2004;80:610-2.

25. Alao O, Damulak D, Joseph D, Puepet F. Haemostatic Profile of Patients with Type 2 Diabetes Mellitus in Northern Nigeria. Int J Endocrinol 2010;6:122-32.

26. Iloh G, Amadi A, Ebirim C. Type 2 Diabetes Mellitus in Ambulatory Adult Nigerians: Prevalence and Associated Family Biosocial Factors in a Primary Care Clinic in Eastern Nigeria: A Cross-sectional Study. Br J Med Med Res 2015;9:1-12.

27. Aguiree F, Brown A, Cho NH, et al. IDF Diabetes Atlas: 6th edition. Basel, Switzerland: International Diabetes Federation. 2013.

28. Erem C, Hacıhasanoğlu A, Çelik Ş, et al. Coagulation and Fibrinolysis Parameters in Type 2 Diabetic Patients with and without Diabetic Vascular Complications. Med Princ Pract $2005 ; 14: 22-30$.

29. Nordström A, Hadrévi J, Olsson T, et al. Higher Prevalence of Type 2 Diabetes in Men Than in Women Is Associated With Differences in Visceral Fat Mass. J Endocrinol Metab 2016;101:3740-6.

30. Lipscombe LL, Hux JE. Trends in diabetes prevalence, incidence, and mortality in Ontario, Canada 1995-2005: a population-based study. Lancet 2007;369:750-6.

31. Fadupin G, Joseph E, Keshinro O. Prevalence of obesity among type 2 diabetics in

Nigeria a case study of patients in Ibadan, Oyo State, Nigeria. Afr J Med Med Sci 2004;33:381-4.

32. Mugharbel KM, Al-Mansouri MA. Prevalence of obesity among type 2 diabetic patients in Al-khobar primary health care centers. J Family Community Med 2003;10:49-53. 
33. Karim F, Akter Q, Jahan S, et al. Coagulation impairment in Type 2 Diabetes Mellitus. J Bangladesh Soc Physiol 2015;10:26-9.

34. Zhao Y, Zhang J, Zhang J, Wu J. Diabetes Mellitus is associated with shortened activated partial thromboplastin time and increased fibrinogen values. PLoS ONE 2011;6:1-4.

35. Adonu C, Ugwu PC, Bawa A, et al. Intrinsic Blood Coagulation Studies in Patients Suffering from both Diabetes and Hypertension. Int J Pharm Med Bio Sci 2013;2:36-45.

36. Bae SH, Lee J, Roh KH, Kim J. Platelet activation in patients with diabetic retinopathy. Korean J Opthalmol 2003;17:140-4.

37. Acang N, Jalil FD. Hypercoagulation in diabetes mellitus. Southeast Asian J Trop Med Public Health 1993;24:263-6.

38. Odusan O, Olayemi O, Raimi H, et al. A study of hemorrhological parameters as risk factors for cardiovascular diseases in Nigerian type 2 diabetes mellitus patients. Nig J Cardiol 2013;10:72.
39. Kannel W, D'Agostino R, Wilson P, et al. Diabetes, fibrinogen, and risk of cardiovascular disease: The Framingham experience. Am Heart J 1990;120:672-6.

40. Festa A, D'Agostino R, Tracy R, Haffner S. Elevated Levels of Acute-Phase Proteins and Plasminogen Activator Inhibitor-1 Predict the Development of Type 2 Diabetes: The Insulin Resistance Atherosclerosis Study. Diabetes 2002;51:1131-7.

41. Soares A, Sousa M, Fernandes A, Carvalho M. Hemostatic changes in patients with type 2 diabetes mellitus. Rev Bras Hematol Hemoter 2010;32:482-8.

42. Grant PJ. Diabetes mellitus as a prothrombotic condition. J Inter Med 2007;262:157-72.

43. Yarmolinsky J, Barbieri NB, Weinmann T, et al. Plasminogen activator inhibitor- 1 and type 2 diabetes : a systematic review and metaanalysisof observational studies. Nat Publ Gr 2016;8:1-13. 